\section{Campaign to close Semipalatinsk}

\section{Moscow}

A MOVEMENT whose goal is a moratorium on nuclear testing by the United States and the Soviet Union is making some headway. Last month, the organization, called the Nevada-Semipalatinsk AntiNuclear Public Movement, called on presidents Mikhail Gorbachev and George Bush to put an end to underground weapons tests.

The president of the movement, the prominent Soviet Kazakh poet Olzhas Suleiminov, who is also now a People's Deputy of the USSR, says that the "immediate goal is to close the testingground in Semipalatinsk (in Kazakhstan). But Suleiminov added that the goal will be attainable only if there is "simultaneous closure of the Nevada testing ground".

The movement was founded at the end of February this year, with a rally at Alma Ata, the capital of Soviet Kazakhstan. Its general aim is to put an end to nuclear testing anywhere in the world. The organization is hoping to pool its efforts with those of similar groups in the United States, for which purpose a member of the movement's coordinating council has visited the United States, meeting among others Dr Bernard Lown, co-chairman of International Physicians for the Prevention of Nuclear War.

The Neveda-Semipalatinsk movement accuses the Soviet authorities of concealing the consequences of the testing programme in East Kazakhstan. The group's formal statement says that both ill-health and mortality increased in the neighbourhood of the testing-grounds over the forty years they have been in use, adding that "this was concealed from us". It complains that problems occasioned for public health and the environment during the testing programme were neglected.

The report of an expert commission formed on the instructions of the Soviet government, which concludes that the radiation in Semipalatinsk and surrounding districts is normal, has been met mildly speaking - with open mistrust by the local people. The letters with which state and public offices have since been deluged have been full of tales of suffering and sorrow.

E.I.Proskurina, born in Semipalatinsk in 1936, says that "everything that once made me a woman was cut out, and I do not know who I am now". Zh. Zhuniszhanov describes having seen "with our own eyes enormous blinding glows which turned into mushroom clouds ... the gullibility was so great that we did not feel the danger and did not attach any importance to these sights".

Among the letters is one from 20 war and labour veterans who say they were, like others in the Abai district, subjected to radiation from the testing of a hydrogen bomb in 1953. In the rural area of Sarzhai, 240 people are under medical supervision. Cancer, anaemia, allergy and neurosis are common, child mortality is high and suicides among young people have become more frequent.

Although there have been only underground tests since 1963, they have caused repeated emissions of radioactive gases, most recently on 12 February, and background radiation has been increasing. The effects of seismic stress are another source of trouble. A public opinion poll carried out in May and June showed that 99 per

\section{London}

THE Byelorussian Academy of Sciences is highly critical of the standards of radiation safety that were proposed by Moscow experts in the aftermath of the Chernobyl disaster, the president of the academy, Dr Uladzimir Platonau, told a recent session of the Byelorussian Supreme Soviet (parliament).

The Moscow experts from the Ministry of Health Protection and the All-Union Academy of Medical Sciences set a maximum lifetime radiation dose of 35 rems. People living in regions of greater risk are to be evacuated. But the caesium137 pollution from Chernobyl is proving more extensive and far more difficult to remove than was originally estimated, and more than 103,000 inhabitants of the Byelorussian republic now face evacuation. Nevertheless, say the Byelorussian scientists, this limit is not only scientifically doubtful but is also "amoral". How, Platonau asked his fellow parliamentarians, can one have the same, artificial limit for adults, children, pregnant women and invalids? The real criterion, according to the academy, Platonau said, should be whether or not normal life can be sustained in a given area.

Approximately one-fifth of all agricultural land in Byelorussia is at present unfit for agriculture, and the residents of these erstwhile collective and state farms have to be supplied with milk, meat and vegetable products from outside. The cost of this operation is so high that, according to one Byelorussian estimate, if the whole of the contaminated area were evacuated, the outlay, including building new homes, schools and amenities, would pay for itself in eight years.

Platonau's proposal is less drastic and more democratic. He suggests that a maximum lifetime dose of 7 rem (the international standard for nuclear power station construction) should be adopted as cent of the inhabitants of three districts adjacent to Semipalatinsk felt unwell the day after an explosion, and that 99.5 per cent are convinced that the testing-ground endangers their health.

Saim Balmukhanov, a member of the Kazakhstan Academy of Sciences, says that the number of people suffering from blood diseases has doubled since 1970 and that infant mortality has risen sharply, to 43.5 deaths per 1,000 newborns. Now, in a street in central Semipalatinsk, there is a drugstore in whose window can be seen a dosimeter showing the radiation level in the city, put there at the urging of the movement that seeks a moratorium on nuclear testing.

Vladimir Lysenkov/Novosti

\title{
Byelorussian criticism
}

an evacuation threshold. People living in areas of higher risk should be given the fullest possible information about the degree of pollution and the risk factors, and should then be given the option of evacuation.

Ever since the Chernobyl accident, in April 1986, Platonau and his academy colleagues have been concerned about the consequences for Byelorussia, but have received short shrift from Moscow. Two years ago, he told the Supreme Soviet, they had put a number of questions about radiation safety standards to the Moscow experts, only to be told that "you are not medical experts, and there is no need to discuss these doubts further". It is true, Platonau said, that the Byelorussian Academy has no medical institute, and that its Institute of Radiobiology was founded only in 1987. Nevertheless, during the past year, Platonau said, he has been collecting all relevant data on radiation safety from his biologist and chemist colleagues. This material, he said, "has made it possible to draw the attention of the broad scientific community and the leaders of our country to the fact that the situation is far more complicated than certain comrades imagined". The Byelorussian concern about post-Chernobyl health risks is shared by the Ukrainian Academy of Sciences, which also queries the scientific validity of the 35-rem limit, and whose president, Dr Borys Paton, has proposed a moratorium on nuclear power construction until a safer generation of reactors is available, and the health risks better understood. Somewhat unexpectedly, the All-Union Party daily Pravda has shown itself to be sympathetic to the Byelorussian case, even emphasizing, for example, the shortage of diagnostic equipment to examine children with thyroid problems associated with iodine131 fallout from Chernobyl.

Vera Rich 